\title{
BRAIN NATRIURETIC PEPTIDE (BNP)
}

\author{
Isbandiyah*
}

\begin{abstract}
Abstrak
Gagal jantung merupakan suatu sindroma klinik dengan tanda dan gejala yang disebabkan disfungsi ventrikel kiri. Untuk menghemat biaya perawatan dan pengobatan diperlukan diagnosis yang cepat dan akurat, serta strategi pengobatan yang tepat, yaitu antara lain dengan mengukur nilai brain natriuretic peptide (BNP). BNP adalah suatu neurohormon jantung, terutama dihasilkan oleh ventrikel sebagai respon terhadap expansi volume ventrikel, tekanan yang berlebiban (overload), dan meningkatnya tekanan dinding ventrikel.

Dua metode dalam pemeriksaan BNP, yaitu metode radioimmunoassay (RIA) dan immunoradiometricassay (IRMA) atau fluorescence immunoassay (FI). BNP dapat digunakan untuk diagnosis gagal jantung dengan cepat, untuk. membedakan sesak karena gagal jantung dengan akibat penyakit lain, pemeriksaan (screening) gangguan sistolik ventrikular kiri pada pasien setelab serangan infark miokard, sebagai monitoring gagal jantung dan juga indikator prognosis gagal jantung. Nesiritid sebagai buman recombinant dari BNP dapat digunakan sebagai terapi pasien gagal jantung.

Pada akbirnya BNP tidak bisa mengganti peran ekokardiografi, tetapi sebagai alat pelengkap, hal ini karena BNP tidak dapat membedakan antara disfungsi diastolik dan sistolik dan tidak memberikan informasi tentang kelainan katub dan fungsinya.
\end{abstract}

\section{PENDAHULUAN}

Gagal jantung merupakan suatu sindroma klinik dengan tanda dan gejala yang disebabkan disfungsi ventrikel kiri (Struthers AD. 2001). Penyakit ini merupakan penyebab utama mortalitas dan morbiditas, serta merupakan salah satu penyebab meningkatnya pasien masuk rumah sakit di negara berkembang, dengan prevalensi sekitar $0,4-2 \%{ }^{(2)}$. Hal ini bertanggung jawab terhadap tingginya biaya perawatan kesehatan. Untuk itu penting dalam menentukan diagnosis yang akurat serta strategi pengobatan yang tepat. Pada umumnya gagal jantung didiagnosis saat muncul gejala sesak nafas atau adanya tanda-tanda retensi cairan yang ditemukan pada pasien yang dicurigai mempunyai gagal jantung. Tetapi gejala dan tanda yang ditemukan ini kadang sulit untuk mendukung diagnosis pada keadaan emergensi. Disfungsi jantung merupakan elemen penting pada diagnosis gagal jantung, dan penyebab terbanyak adalah disfungsi sistolik ventrikel kiri oleh karena kelainan myokard (Struthers AD. 2001).

Untuk menghemat biaya perawatan serta pengobatan pasien gagal jantung, diagnosis yang cepat dan akurat serta membedakan dengan penyakit lainnya harus segera dilakukan. Walaupun

\footnotetext{
* Staff Pengajar Pada Fakultas Kedokteran

Universitas Muhammadiyah Malang
}

echocardiography dinyatakan sebagai gold standart untuk deteksi disfungsi ventrikel, selain mahal, hal ini tidak mudah dan mungkin tidak selalu mencerminkan kondisi akut Bhatia V, Nayyar P, Dhindsa S. 2003). Salah satu alat diagnosis yang cepat dan potensial adalah dengan mengukur nilai brain natriuretic peptide (BNP).

BNP adalah suatu neurohormon jantung, terutama dihasilkan oleh ventrikel sebagai respon terhadap expansi volume ventrikel, tekanan yang berlebihan (overload), dan meningkatnya tekanan dinding ventrikel (Bhatia V, Nayyar P, Dhindsa S. 2003; Denus S, Pharand C, and Williamson DR. 2004; Hill JA; Peacock WF. 2002; Levin ER, Gardner DG, Samson WK. 1998). Oleh karena itu BNP dapat digunakan sebagai alat untuk diagnosis dini (predictor) adanya disfungsi ventrikel baik pada pasien rawat jalan maupun pasien emergensi. Selain itu BNP dapat digunakan untuk monitor respon terapi dan prognosis gagal jantung, serta dapat digunakan sebagai terapi gagal jantung.

Tujuan dari penulisan makalah ini adalah untuk mengetahui lebih jauh tentang BNP, baik biomolekuler, fungsi fisiologis, cara mengukur BNP, serta aplikasi klinisnya. Dengan memahami BNP diharapkan kita semua dapat mendiagnosa dengan cepat, dan pasien akan segera mendapat terapi yang cepat dan proporsional, dengan demikian kita 
dapat membantu menurunkan morbiditas dan mortalitas karena gagal jantung.

\section{Patofisiologi Gagal Jantung}

Gagal jantung merupakan sindroma klinik yang sangat kompleks akibat setiap kelainan yang menyebabkan gangguan kemampuan ventrikel untuk memompakan darah ke seluruh tubuh (Gorenjak M; Peacock WF. 2002; Francis GS. Gassler JP, Sonnenblick EH. 2001) Gagal jantung dapat disebabkan oleh kelainan pada myokard, pericardi, endokard, beban volume, beban tekanan dan lain sebagainya. Sebanyak $80-90 \%$ penderita gagal jantung menunjukkan disfungsi ventrikel dengan spectrum yang sangat luas, mulai dari disfungsi diastolic yang predominan dengan ukuran ventrikel normal, pengosongan normal tetapi pengisian berkurang, sampai dengan disfungsi sistolik yang predominan disertai pelebaran ruang ventrikel dengan gerakan dinding yang sangat berkurang.

Dua pilar utama dari patofisiologi gagal jantung adalah remodeling myokard dan kelainan fungsi neuroendokrin, berupa aktifasi adrenergik dan perubahan sistim rennin-angiotensin-aldosteron (RAAS) yang mengakibatkan terjadinya disfungsi ventrikel (gambar1).

Baroreseptor menengahi terjadinya peningkatan tonus simpatis pada disfungsi ventrikel, hal ini mempunyai konsekwensi meningkatnya kontraktilitas myokard, takikardi, vasokonstriksi arteri yang selanjutnya meningkatkan afterload jantung, dan kontraksi vena akan menyebabkan meningkatnya preload. Peningkatan konsentrasi norepineprin local maupun norepineprin sirkulasi menyokong terjadinya hipertropi myosit, hal ini melalui stimulasi langsung dari reseptor adrenergik á1 dan â atau sekunder oleh aktifasi sistim rennin-angiotensin-aldosteron. Melalui vasokonstriksi ginjal, stimulasi sistim renninangiotensin -aldosteron dan pengaruh langsung pada tubulus proximalis meningkatkan aktifitas adrenergik ginjal, ini menyokong retensi sodium dan air yang terjadi pada pasien gagal jantung ( Francis GS. Gassler JP, Sonnenblick EH. 2001; Jessup $M$ and Brozena S. 2003; Schrier RW and Abrabam WT. 1999)

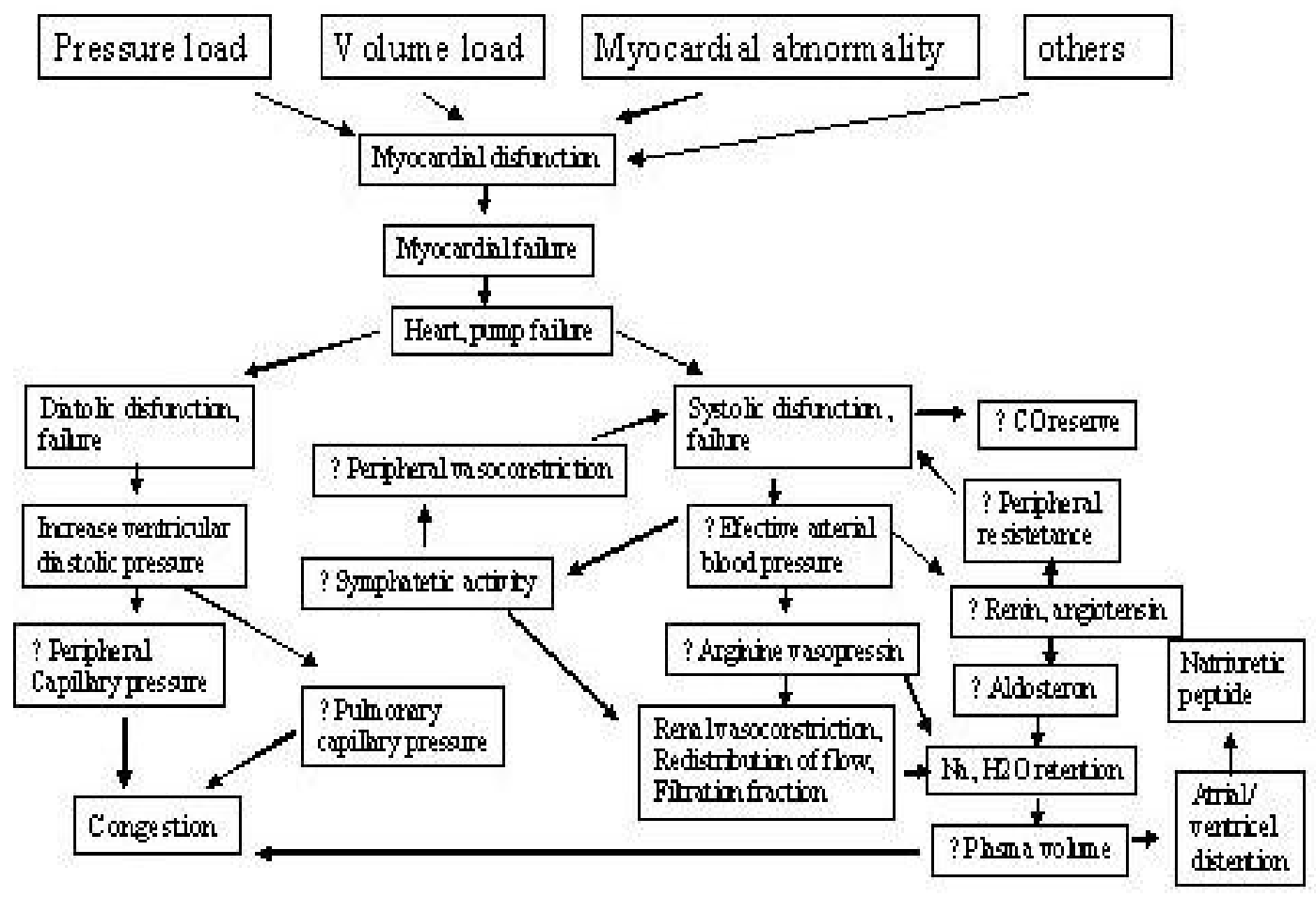

Gambar 1. Patofisiologi gagal jantung (the heart 10th Ed) 


\section{NATRIURETIC PEPTIDE}

Natriuretic peptide adalah suatu kelompok peptida yang struktur molekulnya mirip tetapi secara genetic berbeda. Keluarga natriuretic peptide terdiri dari 3 peptida yaitu: atrial natriuretic peptide (ANP), B-type natriuretic peptide atau brain natriuretic peptide (BNP), dan C-type natriuretic peptide (CNP). ANP dan BNP berasal dari jantung, sedang CNP berasal dari endotel vaskuler. Precursor prohormon untuk masing-masing disandi oleh gen yang berbeda, distribusi jaringannya spesifik, dan regulasi masing-masing peptida juga berbeda (Struthers AD. 2001; Gorenjak M. Kelly R; Levin ER, Gardner DG, Samson WK. 1998; Ruscoabo H. 2003)

Atrial natriuretic peptide adalah suatu peptida yang terdiri dari 28 asam amino, terutama diproduksi oleh atrium jantung dan dalam jumlah sedikit diproduksi oleh ventrikel. ANP disimpan dalam granula atrium sebagai C-terminal dari 126 asam amino prohormon (proANP).pada sekresinya prohormon 1-126 dipecah oleh protease corin menjadi N-terminal 98 asam amino (N-ANP 198) dan bentuk aktif ANP 99-126. ANP dengan cepat dipindahkan dari sirkulasi terutama melalui ikatannya dengan reseptor dan dihidrolisa oleh endopeptidase neutral. Level plasma ANP bervariasi dan dapat diukur melalui suatu tahap ektraksi. NANP kurang bervariasi dan mempunyai waktu paruh lebih panjang di dalm sirkulasi, untuk itu NANP lebih representatif sebagai marker overload jantung dari pada ANP (Ruscoabo H. 2003)

ANP pada dosis rendah akan menurunkan resistensi vaskuler perifer dan menurunkan tekanan darah, tetapi pada dosis tinggi justru meningkatkan resistensi vaskuler perifer meskipun tekanan darah menurun. Menurunnya tekanan darah disebabkan karena berkurangnya preload jantung akibat bergesernya cairan intravaskuler kedalam ekstravaskuler. Selain itu ANP juga meningkatkan kapasitas vena dan mendorong natriuresis yang mengurangi volume cairan ekstraseluler (Levin ER, Gardner DG, Samson WK. 1998) Kerja langsung ANP pada ginjal yaitudilatasi arteriol afferen dan konstriksi arteriol efferensehingga tekanan didalam glomerulus meningkat, mengakibatkan meningkatnya filtarasi glomerulus; ANP juga meningkatkan akukulasi cGMP pada sel mesangial sehingga memperluas daerah permukaan filtrasi. ANP menghambat transport sodium, menurunkan sekresi rennin dan menghambat pelepasan aldosteron, menghambat transport air di tubulus. Beberapa hormon dan neurotransmitter seperti endotelin, arginin vasopresin dan katekolamin secara langsung merangasang sekresi ANP. Peningkatan tekanan dinding atrium, meningkatnya volume intravaskuler merupakan rangsangan utama untuk pelepasan ANP. (Levin ER, Gardner DG, Samson WK. 1998)

Brain Natriuretic peptide asalnya diidentifikasi dari otak babi, terutama banyak diproduksi di ventrikel jantung, dalam jumlah sedikit terdapat pada otak manusia. Pro brain natriuretic peptide menusia terdiri dari 108 asam amino dan mengalami proses pemecahan molekul 32 asam amino dan fragmen amino terminal. Keduanya beredar dalam plasma dan konsentrasinya tinggi pada pasien dengan hipertropi ventrikel atau gagal jantung kongestif. (Levin ER, Gardner DG, Samson WK. 1998)

C-type natriuretic peptide terdiri dari 22 asam amino dan 53 asam amino, diproduksi oleh endotel vascular dan mempunyai efek vasodilator dan anti proliperatif pada otot polos vascular ${ }^{(11)}$. Bentuk 22 asam amino juga terdapat pada CNS, pituitary anterior, ginjal, dan plasma dan merupakn bentuk yang lebih poten dari pada 53 asam amino (Levin ER, Gardner DG, Samson WK. 1998; Ruscoabo H. 2003)

Masing-masing natriuretic peptide juga mempunyai efek antimitogenik, ANP dan CNP menghambat mitogenesis pada sel vaskuler, hal ini menunjukkan bahwa natriuretic peptide dapat memodulasi pertumbuhan didalam dinding vaskuler pada proses aterosklerosis, hiperetnsi, dan post angioplasty restenosis (Struthers AD. 2001)

Natriuretic peptide menggunakan efeknya melalui interaksi dengan reseptornya dengan afinitas tinggi pada permukaan target sel. Tiga reseptor natriuretic peptide telah dikenal yaitu: $A, B$, dan $C$. A dan B berhubungkan dengan cGMP dan menengahi terjadinya efek kardiovaskuler serta efek pada ginjal. Reseptor A mengikat ANP dan BNP terutama ANP, reseptor B mengikat CNP. Reseptor A adalah reseptor terbanyak pada pembuluh darah, reseptor $\mathrm{C}$ terkait pada kliren peptida. 


\section{BNP, BIOSINTESA DAN MOLEKULER}

Brain Natriuretic peptide (BNP) yang juga disebut B-type natriuretic peptide adalah anggota famili hormon natriuretic peptide. BNP terdiri dari 32 asam amino, diisolasi pertama kali dari otak babi. Pada konsentrasi fisiologis, neurohormon ini berperan pada keseimbangan cairan tubuh dan tonus vaskuler.

Pada manusia BNP terutama disekresi oleh jantung, dan terbanyak dari ventrikel, baik pada orang sehat maupun pada pasien dengan gagal jantung kongestif. BNP tampaknya menjadi satusatunya natriuretic peptide yang spesifik untuk ventrikel, precursor BNP (pro-BNP) disimpan dalam granula sekresi dalam myosit ventrikel, setelah disintesa di ventrikel pro-BNP dipotong sebagian oleh protease menjadi bentuk aktif dan N-terminal pro BNP (NT-pro BNP) yang terdiri dari 76 asam amino dan merupakan bentuk inaktif BNP. Dibanding BNP aktif, NT-pro BNP mempunyai waktu paruh yang lebih panjang dan tidak dipengaruhi oleh pemberian BNP dari luar seperti nesiritide.

Ekpresi gen dan sekresi BNP dari ventrikel terjadi lebih cepat dari pada ANP pada overload cairan akut, hal ini menunjukkan bahwa BNP berperan sebagai neurohormon emergensi, sehingga BNP dipertimbangkan lebih superior dibanding ANP sebagai marker diagnosis yang potensial pada gagal jantung akut. Pada orang sehat tanpa kelainan kardiovaskuler, level BNP tergantung pada jenis kelamin dan umur, wanita mempunyai konsentrasi plasma yang lebih tinggi dibanding laki-laki, tetapi level BNP sama meningkatnya pada laki-laki dan wanita usia lanjut.

BNP berasal dari pre-proBNP, suatu 134 peptida asam amino yang kemudian mengalami degradasi menjadi pro-BNP (108 asam amino). Pro-BNP diregulasi pada tingkat gen dan tidak membentuk granul. Pro-BNP selanjutnya dipecah menjadi N-terminal pro-BNP (1-76 asam amino, yang secara biologi merupakan bentuk yang tidak aktif (gambar 2). Keduanya dilepaskan dalam sirkulasi darah, dalam molaritas yang sama. Dibandingkan dengan BNP, NT-proBNP lebih besar dan memiliki waktu paruh yang lebih panjang (90 menit). NT-proBNP dalam sirkulasi memiliki kadar yang lebih tinggi dibandingkan BNP dan lebih mudah diukur. Secara invitro, stabilitas NTproBNP lebih baik dibanding BNP. Bentuk BNP aktif, terdiri dari 32 asam amino dengan 17 cincin asam amino tertutup oleh ikatan disulfida diantara dua cystein. (gambar 3).

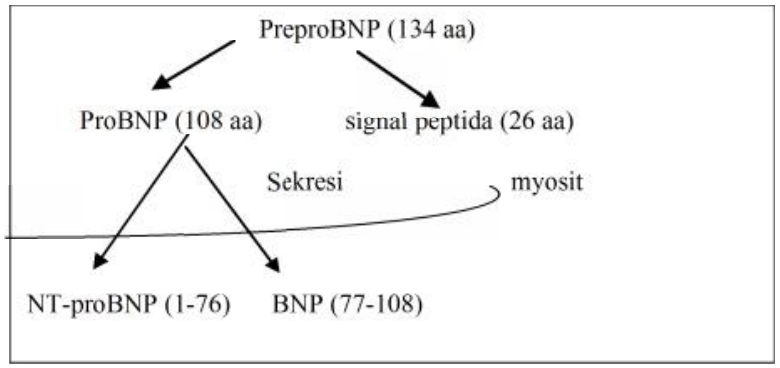

Gambar 2. Pembentukan BNP dan proBNP

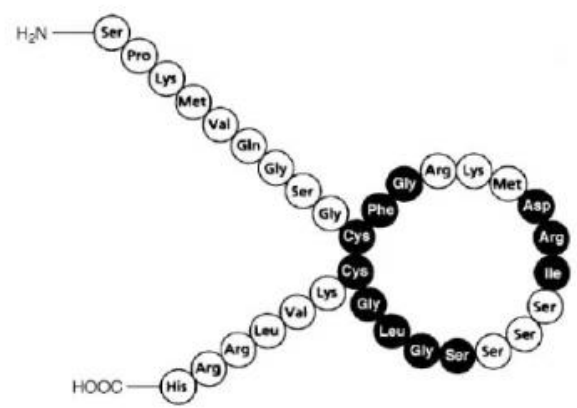

BNP-32-the biologically active hormon Gambar 3. Bentuk molekul BNP

\section{MEKANISME FISIOLOGI BNP}

BNP mempunyai peran penting pada gagal jantung kongestif sebagai konterregulasi hormon terhadap angiotensin II, norephinephrin, dan endotelin, hal ini oleh karena menurunkan sintesa dari beberapa neurohormon tersebut dan bekerja sebagai balance vasodilator (gambar 4). Selanjutnya sebagai hasil pengaruh hemodinamiknya dan kerja langsung pada tubulus, BNP mempunyai pengaruh natriuresis dan diuresis. Pada vasculer perifer BNP menurunkan tonus simpatis dengan mengurangi baroreseptor, dengan menekan pelepasan katekolamin dari saraf autonom, dan dengan menekan keluarnya simpatis dari CNS. BNP menurunkan aktifasi nilai ambang vagal aferen, menekan reflek takikardi dan vasokonstriksi yang disertai menurunnya preload jantung dan menjamin tahanan beban menurun pada tekanan arteri ratarata. BNP merangsang dilatasi arteriol afferen ginjal dan konstriksi arteriol efferent, hal ini meningkatkan tekanan dalam kapiler glomerulus dan menyebabkan peningkatan filtrasi glomerulus. BNP juga 
meningkatkan akumulasi cGMP pada sel mesangial, yang mana menyebabakan relaksasi sel mesangial dan selanjutnya meningkatkan area permukaan efektif untuk filtrasi. BNP menghambat transport sodium pada duktus koledokus, menurunkan sekresi rennin dari macula densa, menghambat pelepasan aldosteron dan menghambat transport air dengan kerja antagonisnya terhadap vasopresin.

Dibanding dengan neurohormon yang lain, plasma BNP berhubungan dengan tekanan kapiler pulmonum, tekanan akhir diastolic ventrikel dan fraksi ejeksi ventrikel kiri. Pada beberapa studi menunjukkan bahwa pada pasien dengan disfungsi sistolik ventrikel, konsentrasi BNP meningkat dengan memberatnya penyakit secara klinis sesuai dengan klasifikasi New York Heart Association (NYHA). Data lain menunjukkan bahwa plasma BNP merupakan predictor yang kuat dari penurunan kapasitas latihan yang diukur dengan uptake oksigen latihan pada pasien dengan gagal jantung kongestif. Penelitian lain menunjukkan bahwa konsentrasi BNP juga meningkat pada pasien dengan disfungsi diastolic dan hipertropi ventrikel kiri, hal ini mengindikasikan bahwa pelepasan BNP meningkat pada kelainan fungsi ventrikel kiri dan bahwa meningkatnya regangan dinding ventrikel dan meningkatnya tekanan pengisian ventrikel bertanggung jawab terhadap meningkatnya sekresi ini.

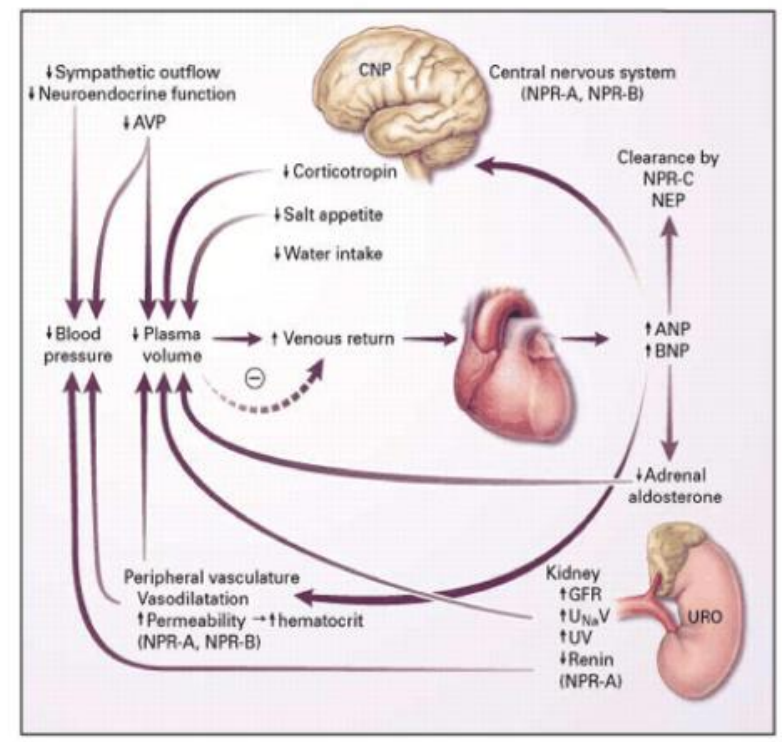

Gambar 4. Fisiologi BNP pada gagal jantung (CHEST 2004; 125: 652-668)

\section{PENGUKURAN DAN NILAI PLASMA BNP}

Terdapat dua metode dalam pemeriksaan BNP, yaitu metode radioimmunoassay (RIA) dan immunoradiometricassay (IRMA) atau fluorescence immunoassay (FI). Metode RIA telah diperkenalkan sejak 10 tahun lalu, metode ini dilakukan secara tidak langsung yaitu melalui ektraksi, sample pertama kali diinkubasi dengan BNP-antibody selama 24 jam kemudian ditambahkan ${ }^{125} \mathrm{I}-\mathrm{BNP}$, diinkubasi lagi 24 jam untuk meningkatkan sensitifitas. Antigen bebas biasanya dipisahkan dari kompleks antigenantibody dengan polyethyleneglycol dengan cara sentrifuge.

Ketika akan dipersiapkan untuk pemeriksaan ekstrak dibutuhkan volume plasma yang cukup besar dan tekanan yang lebih tinggi. Untuk kebanyakan radioimmunoissay tekanan tergantung pada konsentrasi, tetapi beberapa penelitian melaporkan profilnya secara tepat pada kurva dosis-respon. Level plasma BNP pada manusia tidak didistribusikan secara normal, tetapi kebanyakan penulis memberikan nilai rata-rata: means $\pm \mathrm{SD}$, dengan nilai rata-rata dari laboratorium yang berbeda berkisar 2-22 pg/mL. Dari beberapa sumber variasi harga normal yang dilaporkan beberapa laboratorium yang berbeda membuat sulit untuk menentukan standart BNP internasional, tetapi factor lain seperti perbedaan metode juga penting untuk diperhatikan. Pada kondisi klinik yang berhubungan dan level plasma yang muncul pada gangguan jantung bergantung pada keparahan kondisi dan dapat menjadi tinggi. Level bisa menjadi 20X lebih tinggi pada CRF yang didialisis, dan > $100 \mathrm{X}$ pada penderita dengan kardiomyopati obstruktif hipertropi. Tetapi ini bergantung juga pada variasi individu dan tingkat keparahan dari kerusakan jantung dan atau ginjal. Metode ini memerlukan waktu sekitar 3 hari dengan jumlah sample lebih dari $10 \mathrm{~mL}$, sehingga menjadi problem jika hasilnya diperlukan secepatnya.

Pada metode IRMA tidak diperlukan ektraksi, jadi merupakan metode langsung atau direct assay, menggunakan dua monoclonal antibody dan membutuhkan inkubasi selam 20 jam, sample yang dibutuhkan hanya 100uL. Secara keseluruhan metode IRMA lebih sensitive dan mempunyai profil yang lebih bagus dari RIA.

Sample darah diambil dari darah vena, kemudian ditambah EDTA dimasukkan tabung lalu disentrifuge pada suhu $4{ }^{\circ} \mathrm{C}$, plasma 
dimasukkan dalam tabung plastik dan didinginkan pada suhu $-20{ }^{\circ} \mathrm{C}$. Peptida stabil pada suhu $-20{ }^{\circ} \mathrm{C}$ selama 2-3 bulan, jika diperlukan disimpan lebih lama maka disarankan disimpan pada suhu yang lebih rendah lagi. Nilai range $\mathrm{BN}$ sekitar 3 sampai $1300 \mathrm{pg} / \mathrm{mL}$, dengan cut off $100 \mathrm{pg} / \mathrm{mL}$, nilai ini bervariasi ${ }^{(6,11,12)}$. Konsentrasi plasma BNP meningkat pada pasien yang secara klinis didiagnosis CHF dibanding pasien tanpa CHF $(675 \mathrm{pg} / \mathrm{mL}$ lawan $110 \mathrm{pg} / \mathrm{mL}$ ). Pada pasien dengan disfungsi ventrikel kiri tanpa exaserbasi akut nilai plasma BNP 346 $\mathrm{pg} / \mathrm{mL}$. Plasma BNP . $100 \mathrm{pg} / \mathrm{mL}$ diagnosis CHF dengan sensitivitas $90 \%$, spesifisitas $76 \%$, dan nilai prediksi $83 \%$.

Ada beberapa faktor yang perlu diperhatikan dan berpengaruh terhadap kenaikan nilai level BNP, yaitu: usia, jenis kelamin, pasien sirosis hati, gagal ginjal, hipertropi ventrikel kiri, atau kondisi lain seperti myokarditis, hipertensi pulmonal primer, hiperaldosteronisme primer, sindroma cushing.

\section{APLIKASI KLINIS BNP \\ Sebagai alat diagnosis gagal jantung}

Konsentrasi plasma BNP meningkat pada penderita dengan asimptomatis dan simptomatis disfungsi ventrikel kiri, alasan ini digunakan sebagai nilai diagnosis pemeriksaan yang cepat dari plasma BNP untuk membedakan antara CHF dan penyebab sesak yang lain, misalnya karena paru, ini telah dievaluasi pada tujuh penelitian multinasional di ruang gawat darurat dengan keluhan sesak mendadak. Plasma BNP lebih meningkat pada penderita yang secara klinis didiagnosis CHF dibanding mereka yang tanpa CHF.

Bukti bagi peran BNP dalam diagnosis gagal jantung telah diperoleh baik dalam setting pengobatan rawat jalan maupun pasien yang memerlukan pengobatan segera. Dua populasi sangat berbeda; pasien yang terbukti akut biasanya lebih terganggu secara fungsional dengan durasi gejala lebih pendek dan etiologi yang lebih sering adalah penyakit koroner akut. Di antara pasien rawat jalan, gejala-gejala tersebut mungkin lebih ringan dan serangannya lebih tersembunyi, membuat diagnosis lebih sulit; hanya separoh pasien yang diduga terkena gagal jantung memiliki diagnosis yang dikonfirmasikan pada perkiraan lebih penuh oleh kardiologis. Dalam Hillingdon Heart Failure Study berdasarkan populasi, satu pertiga pasien yang secara klinis terdiagnose gagal jantung oleh dokter pertama yang mengobati yang telah dikonfirmasikan dengan pemeriksaan lebih lanjut. Nilai diagnostik konsentrasi plasma BNP dibanding dengan opini klinis panel ahli sangat tinggi. Area kurva dalam karakteristik penerima operasi (ROC) untuk plasma BNP adalah 0.96, dibanding dengan 0.79 untuk rasio kardiotorax pada sinar-X thorax

Akurasi diagnosis kegagalan jantung dengan tujuan klinis dan pengujian standart seringkali tidak layak dalam setting perawatan emergensi. Dalam studi Breathing Not Properly (BNP), yang dilakukan di pusat akademis Amerika Utara dan Eropa, lebih dari 40\% dokter ruang emergensi menunjukkan tidak adanya keputusan yang signifikan mengenai diagnosis ketika digabungkan dengan nilai-nilai BNP. Konsentrasi plasma BNP diidentifikasi sebagai prediktor independen dalam gagal jantung. Dalam studi ini, penggunaan titik potong plasma BNP $100 \mathrm{pg} / \mathrm{ml}$ memberi kepekaan $90 \%$ (95\% konfiden interval $88-92 \%)$ dan spesifitas 76\% (73-79\%). BNP secara siginifikan lebih akurat dibanding penilaian klinis dan metode diagnosis tradisional dalam mengidentifikasi pasien dengan gagal jantung Jumlah pasien dengan dignosa yang tidak pasti mengalami penurunan dari $43 \%$ sampai $11 \%$ ( $p=$ 0.0001).

Kenaikan plasma BNP dapat memastikan adanya $\mathrm{CHF}$ oleh karena disfungsi diastolic dengan akurasi mirip dengan disfungsi sistolik. Bagaimanapun nilai ini tidak membedakan antara disfungsi sistolik dan diastolic. Berdasar data ini, BNP disetujui oleh FDA untuk keperluan diagnosis CHF. Plasma BNP juga meningkat pada penderita dengan hipertensi pulmonal dan disfungsi ventrikel kanan. Pada penderita seperti ini berkaitan secara positif dengan tekanan rata-rata arteri pulmonal, resistensi pulmonal total, dan massa ventrikel kanan

Meski begitu, penting untuk diingat bahwa BNP bukan merupakan uji diagnostik yang berdiri sendiri. Uji harus digunakan dan diinterpretasikan dalam konteks klinis yang lebih luas, khususnya yang terkait dengan umur dan gender. Kalangan klinis harus mengetahui bahwa beberapa kondisi klinis dapat merubah interpretasi klinis dari BNP. Ini meliputi ischaemia, infarks dan ketidakmampuan renal, yang dapat menyebabkan berubahnya BNP. Selain itu, penghambat beta bisa mempunyai efek beragam terhadap sirkulasi konsentrasi BNP, dan inhibitor ACE dan diuretik bisa mengurangi konsentrasi BNP. 


\section{Aplikasi Praktek}

Pasien yang mendapat perawatan dasar / rawat jalan:

- Pada pasien baru yang mengalami kegagalan jantung dalam kondisi rawat luar, uji BNP adalah uji "rule-out" untuk gagal jantung.

- Catatan klinis harus dibuat dan perlu menjalankan pemeriksaan fisik. Jika BNP di bawah decision cut-point (normal) maka gagal jantung kecil kemungkinan terjadi dan pasien perlu diperiksa apakah ada masalah lainnya. Jika konsentrasi BNP meningkat maka ada kemungkinan kuat bahwa pasien mempunyai gagal jantung yang perlu diperiksa lebih lanjut. Cara ini merupakan salahsatu tahap dalam buku petunjuk European Society of Cardiology Task Force for Diagnosis and Treatment of Chronic Heart Failure.

- Untuk tujuan klinis prakteknya, "decision cut point" sebesar $100 \mathrm{pg} / \mathrm{ml}$ merupakan akurasi diagnostik optimum. Jika BNP adalah $<100$ $\mathrm{pg} / \mathrm{ml}$ dalam pasien yang tanpa pemeriksaan, maka kemungkinan gagal jantung akan sangat rendah. Decision cut point yang ditetapkan di Eropa untuk NT-proBNP adalah 100 pg/ml untuk pria dan $150 \mathrm{pg} / \mathrm{ml}$ untuk wanita, dan di USA adalah $125 \mathrm{pg} / \mathrm{ml}$ untuk kedua gender.

Pasien yang berada dalam perawatan darurat/ emergensi:

- Dalam pasien baru yang mendapat perawatan darurat karena dyspnoea, catatan klinis, pemeriksaan fisik, dan sinar X dada dan ECG harus dijalankan secara bersamaan dalam uji laboratorium sekaligus melibatkan uji BNP.

Jika BNP $<100 \mathrm{pg} / \mathrm{ml}$, maka kemungkinan gagal jantung adalah sangat kecil.

\section{Pemeriksaan Gangguan Sistolik Ventrikular Kiri}

Dalam kondisi infark miokardial akut, konsentrasi BNP plasma akan meningkat sebanding dengan ukuran infark. Pengukuran BNP bisa menjadi sarana untuk pemeriksaan (screening) untuk gangguan sistolik ventrikular kiri pada pasien setelah terkena infark miokardial (MI), dan juga pada pasien umumnya.

Pada pasien pasca MI, konsentrasi BNP plasma berhubungan terbalik dengan fraksi ejeksi (ejection fraction). Sebuah studi membandingkan konsentrasi BNP plasma dengan echocardiography kuantitatif dan kualitatif, evaluasi klinis dan sistem scoring klinis dalam 75 pasien yang bisa bertahan pada dua hari pertama setelah terkena infark miokard akut. Nilai cut-off sebesar $15 \mathrm{pmol} / 1$ (52 $\mathrm{pg} / \mathrm{ml}$ ) menghasilkan sensitivitas $84 \%$ dan spesifisitas sebesar $62 \%$ untuk deteksi fraksi ejeksi ventrikular kiri sebesar $<40 \%$ pada echocardiography

Dalam studi masyarakat dengan subyek perawatan dasar yang dipilih secara acak (random selection) dalam kisaran umur 25-74 tahun di Glasgow, konsentrasi BNP plasma 5,2 pmol/1 $(17,9 \mathrm{pg} / \mathrm{ml})$ ditemukan mempunyai sensitivitas sebesar 76\% dan spesifisitas $87 \%$ untuk gangguan sistolik ventrikular kiri yang terukur pada echocardiography sebesar EF \& $30 \%$.

Studi perawatan dasar lainnya terhadap subyek berumur 70-84 tahun memperlihatkan bahwa pasien dengan gangguan sistolik ventrikular kiri dengan echocardiography, mempunyai konsentrasi BNP plasma lebih tinggi daripada pasien yang tidak menunjukkan adanya gangguan sistolik (39,3 pmol/1 vs 15,8 pmol/1); area di bawah kurva ROC adalah sebesar 0,85 . Titik cut-off sebesar $18,7 \mathrm{pmol} / 1(64 \mathrm{pg} / \mathrm{ml})$ menghasilkan sensitivitas $92 \%$ dan spesifisitas 65 $\%$ untuk diagnosis gangguan sistolik ventrikular kiri dengan nilai prediktif negatif sebesar 99\% tapi dengan nilai prediktif positif hanya sebesar $18 \%$. Penulis menyimpulkan bahwa pengukuran BNP yang kurang dari 18,7 pmol/l (64 pg/ml) akan menunjukkan adanya signifikansi gangguan sistolik ventrikular kiri.

Meski begitu, studi lain menunjukkan bahwa BNP mempunyai kegunaan diagnostik yang terbatas dalam mengidentifikasi gangguan sistolik ventrikular kiri dalam komunitas. Ini bisa disebabkan oleh konsentrasi BNP plasma yang tidak menunjukkan secara spesifik gangguan sistolik ventrikular kiri dan ukuran peningkatan konsentrasi plasma bisa jauh lebih rendah daripada ukuran yang berada dalam pasien asimtomatik.

\section{Aplikasi Praktek}

Uji BNP tidaklah tepat untuk pemeriksaan populasi asimtomatik yang besar untuk gangguan sistolik ventrikular kiri.

Ada beberapa nilai dalam penggunaan BNP plasma ketika memeriksa sub-kelompok 
populasi beresiko tinggi seperti pasien dengan MI, pasien dengan diabetes atau pasien dengan riwayat hipertensi kronis yang kurang terkontrol, meskipun echocardiography tetap menjadi metode utama dalam menilai fungsi ventrikular kiri.

\section{BNP Sebagai Indikator Prognostik Gagal Jantung}

BNP telah digunakan sebagai sarana untuk mengidentifikasi pasien gagal jantung dengan resiko tinggi untuk kematian atau masuk perawatan rumah sakit, khususnya untuk menjalankan terapi dan memudahkan pemilihan perawatan tersier atau kuarter.

Konsentrasi BNP plasma adalah lebih tinggi pada pasien dengan gejala yang lebih parah dan untuk pasien dengan kerusakan jantung yang lebih parah. Meningkatnya BNP adalah acuan perbedaan antara kerusakan menengah dan kerusakan berat fungsi ventrikular kiri. Selain itu, BNP juga berkorelasi dengan kapasitas proses kardiopulmoner dan dengan ukuran keparahan gagal jantung, seperti nilai ketahanan gagal jantung.

BNP adalah prediktor independen dari kematian dalam pasien dengan gagal jantung kronis, dan bisa menjadi prediktor yang kuat untuk memperkirakan kematian. Dalam studi ini, tiap 10 $\mathrm{pg} / \mathrm{ml}$ peningkatan dalam BNP plasma dikaitkan dengan peningkatan $3 \%$ dalam resiko kematian kardiak pada periode follow-up. BNP juga menjadi prediktor independen untuk segala penyebab kematian dalam pasien dengan asimtomatik atau gangguan ventrikular kiri simtomatik minimal, tapi bisa menjadi prediktor kuat untuk volume norepinephrine dan ventrikular kiri.

Pada pasien dengan gagal jantung akut, BNP bisa menjadi prediktor independen kematian kardiovaskular, dan juga menjadi prediktor untuk pasien dalam perawatan rumah sakit untuk gagal jantung tidak terkontrol. Studi ini menunjukkan bahwa mengukur konsentrasi BNP plasma sebelum proses ejeksi bisa mempermudah identifikasi pasien dengan gagal jantung pada tingkatan resiko yang rendah untuk pemeriksaan bulan berikutnya (area di bawah kurva ROC 0,73).

BNP bisa mempunyai peran dalam memilih pasien gagal jantung untuk dikenai transplantasi. Salah satu studi dijalankan pada pasien dengan fungsi ventrikular kiri akut dan gagal jantung.
Konsentrasi BNP adalah prediktor paling kuat untuk kematian pada kisaran empat tahun proses follow-up. Dalam populasi klinis gagal jantung yang mendapat rawat jalan, BNP plasma adalah yang memiliki ekuivalensi paling rendah untuk nilai ketahanan gagal jantung (yang umumnya digunakan untuk menilai pasien untuk transplantasi) ketika mengukur resikonya.

\section{Aplikasi Praktek}

Dalam pusat pengobatan spesialis, ukuran konsentrasi BNP plasma bisa menjadi sarana penunjang penilaian klinisi untuk berbagai situasi yang membutuhkan penentuan resiko, contohnya dalam memilih pasien dengan gagal jantung yang meningkat sebelum proses transplantasi atau untuk sarana petunjuk guna memudahkan pemilihan (kardioverter-defribilillator, terapi resinkronisasi dan sebagainya).

Studi lebih jauh diperlukan untuk menentukan apakah pengukuran BNP plasma perlu digunakan sebagai pengujian yang berdiri sendiri atau dihubungkan dengan sistem penilaian seperti nilai ketahanan gagal jantung. Proses lebih jauh diperlukan untuk menentukan apakah pengukuran tunggal adalah sarana yang cukup untuk memperkirakan prognosis pasien atau apakah perubahan dalam konsentrasi tiap waktu dan selama perawatan bisa menghasilkan informasi yang lebih banyak

\section{BNP sebagai monitoring Pasien Gagal Jantung}

Konsentrasi BNP plasma diketahui bisa menurun secara cepat pada perawatan pasien gagal jantung. Dalam klinik tertentu, pasien dengan status fungsional yang meningkat antar kunjungan tertentu memperlihatkan penurunan yang secara statistik signifikan dalam konsentrasi BNP plasma sekitar 50\%; variabel lain seperti NT-proANP dan ANP atau fraksi ejeksi memperlihatkan tidak adanya perubahan signifikan secara statistik. Dari data menunjukkan bahwa perawatan vasodilator dapat dititrasikan untuk mengurangi konsentrasi BNP pada pasien tertentu dengan gagal jantung skala ringan sampai sedang.

Meski begitu, monitor terapi dengan mengukur konsentrasi BNP plasma masih dipersulit dengan adanya perbedaan antar level BNP plasma 
pada pasien dengan gagal jantung simtomatik, yang bisa menyebabkan sulitnya titrasi terhadap dosis "target" dari BNP. Data terbaru memperlihatkan adanya peningkatan progresif dalam keragaman aplikasi peptida natriuretik ketika fungsi renal pasien mengalami penurunan. Masih belum jelas penurunan kreatinin yang bagaimana yang diperlukan ketika kondisi tersebut terjadi; kemungkinan tingkatannya masih relatif menengah tapi jelas mempunyai implikasi dalam pengarahan terapi. Penurunan konsentrasi BNP plasma dalam lingkup klinik dengan meningkatkan dosis diuretik bisa memperburuk fungsi renal, yang bisa meningkatkan penurunan BNP. Karena itu, untuk melakukan titrasi obat guna menekan BNP bukanlah cara yang mudah seperti yang dibayangkan.

Ada beberapa bukti tentang keuntungan dari cara BNP terhadap terapi (dengan inhibitor diuretik dan ACE) dari percobaan random yang dijalankan pada 69 pasien dengan gagal jantung simtomatik karena gangguan sistolik ventrikular kiri. Setengah dari jumlah pasien menerima terapi dengan pengukuran NT-proBNP plasma; terapi pada pasien lainnya ditunjang dengan pemeriksaan klinis pada frekuensi yang sama, tapi dalam kondisi bahwa dokter masih belum mengetahui hasil NT-proBNP. Pengawasan klinis didasarkan pada nilai dari 10 gejala atau tanda gagal jantung dalam kriteria Framingham untuk gagal jantung.

Studi menemukan adanya jumlah yang lebih kecil dari kejadian kardiovaskular (kematian, perawatan rumah sakit atau episode tidak terkontrolnya gagal jantung) dalam kelompok terapi NT-proBNP (konsentrasi NT-proBNP target sebesar $200 \mathrm{pmol} / 1$ [1680 pg/ml]) dibandingkan dengan kelompok pasien yang sama dengan variabel klinis umum $(\mathrm{P}=0,02)$. Waktu kardiovaskular pertama dan waktu untuk gagal jantung pertama atau kematian mengalami penundaan atau penghambatan secara signifikan $(\mathrm{P}$ $=0,034$ dan $\mathrm{P}=0,049)$

Studi yang lebih besar dengan target konsentrasi NT-proBNP yang lebih rendah (100 $\mathrm{pmol} / 1$ [840 pg/ml]) dijalankan pada pasien dengan beta-blocker dan spironolactone dan pada pasien dengan inhibitor diuretik dan inhibitor ACE. Studi ini (BAT'TLE-SCARED) bisa menghasilkan bukti yang lebih kuat tentang apakah NT-proBNP bisa atau tidak bisa digunakan sebagai end-point biokimia dalam pengawasan perawatan pasien gagal jantung karena gangguan sistolik ventrikular kiri. Selain itu, studi pada multicenter Rapid Assessment of Badside BNP in Treatment of Heart Failure (RABBIT) atau studi multicenter Perancis Suivi du Traitement dans l'insuffis Ance caRdiaque Systolique (STARS) bisa menjadi jawaban tentang kosentrasi BNP plasma "target" yang tepat.

BNP bisa menemukan sebuah peran untuk memberikan petunjuk terapi terhadap pasien gagal jantung. Sebuah studi yang dijalankan pada pasien dengan gagal jantung stabil dan kronik karena gangguan sistolik ventrikular kiri menunjukkan bahwa karvedilol beta-blocker adalah yang paling berpengaruh pada pasien dengan konsentrasi BNP yang lebih tinggi sebelum-perawatan (di atas 24 $\mathrm{pmol} / 1$ [82,5 pg/ml]). Hipotesis ini tidak diteliti dalam percobaan random prospektif. Meski begitu, temuan NT-proBNP berlaku sama. Penelitian lebih lanjut perlu dilakukan sebelum pengukuran BNP dapat mempunyai peran dalam menghasilkan petunjuk awal beta-blockade (dan terapi lain) dalam gagal jantung.

\section{Aplikasi Praktek}

Masih sedikit sekali data yang bisa digunakan untuk menghasilkan rekomendasi yang terkait dengan level BNP target dan level dimana perawatan harus dirubah. Meski begitu, meningkatnya konsentrasi BNP harus menjadi petunjuk yang penting bagi dokter klinik. Pengawasan reguler BNP bisa juga mempermudah menentukan interval follow-up untuk perencanaan lebih rasional dari discharge dan pembahasan klinis.

\section{BNP untuk terapi gagal jantung}

Oleh karena sekresi natriuretic peptide tubuh sebagai konterregulasi yang menyebabkan penurunan volume intravaskuler, hal ini secara logika dapat dipertimbangkan sebagai terapi untuk pasien gagal jantung. Human BNP telah disintesa menggunakan tekhnologi recombinan, dan disetujui oleh FDA sebagai bahan terapi dengan nama nesiritide (Natrecor) dan dipasarkan oleh Scios. Oleh karena peptida ini identik dengan yang disekresi secara alamiah, efek fisiologi nasiritide mirip dengan kejadian pada BNP, yaitu menurunkan preload dan afterload, dan meningkatkan natriuresis dan diuresis 
Studi pendahuluan pada pasien dengan gagal jantung menunjukkan bahwa pemberian nesiritide intravena menghasilkan dose-dependent vasodilatasi yang diperantarai oleh aktifasi cGMP berpasangan dengan reseptor NPR-A yang berada pada permukaan vaskuler sel otot polos. Nesiritide sebagai vasodilator arteri dan vena, ditunjukkan oleh penurunan tekanan kapiler pulmonal dan resistensi vaskuler perifer, walaupun vasodilatasi arteri secara signifikan hanya tampak pada dosis tinggi; hal ini akan meningkatkan stroke volume dan cardiac index. Oleh karena nesiritide tidak meningkatkan detak jantung, tidak mempunyai efek inotropik positif, dan dapat menghasilkan efek vasodilator pada pembuluh darah epikard, hal ini memungkinkan mempunyai efek yang menguntungkan pada konsumsi oxygen myokard. Nesiritide mempunyai onset kerja yang cepat setelah pemberian bolus $(<15$ menit) dan mempunyai waktu paruh pendek, yang mana mudah untuk titrasi.

Pemberian infus nesiritide juga menurunkan level aldosteron plasma sementara tidak mengahsilkan efek pada rennin, menunjukkan efek hambatan langsung pada glandula adrenal. Hal ini berlawanan dengan nitropusid, yang meningkatkan level aldosteron pada pasien dengan gagal jantung akut. Pada level fisiologi, pemberian BNP mengahasilkan efek hambatan simpatis (sympathoinhibitory effect), sementara aktifitas saraf simpatis tidak dipengaruhi oleh dosis terapi. Nesiritide infus juga menurunkan level endotelin 1 plasma, meningkatkan volume urine, dan exkresi sodium. Apakah efek-efek ini sekunder terhadap perbaikan hemodinamik, bekerja langsung, supresi aldosteron, atau kombinasi masih tetap harus ditegakkan.

\section{RINGKASAN}

BNP adalah natriuretic peptide dihasilkan dan dilepaskan oleh ventrikel sebagai respon terhadap meningkatnya regangan dan tekanan dinding ventrikel. Pengukuran konsentrasi BNP menjadi sesuatu yang berguna pada diagnosis gagal jantung akut pada pasien dengan sesak nafas akut di UGD. Oleh karena BNP tidak dapat membedakan antara disfungsi diastolic dan sistolik dan tidak memberikan informasi tentang kelainan katub dan fungsinya, ini penting untuk digaris bawahi bahwa BNP tidak mengganti peran ekokardiografi, tetapi sebagai alat pelengkap. Konsentrasi BNP juga memegang peranan penting sebagai marker prognosis pasien dengan gagal jantung kongestif dan juga monitor terapi. Akhirnya nesiritid sebagai human recombinant dari BNP menjadi sesuatu yang baru dalam penanganan gagal jantung akut dengan beberapa keuntungan potansial.

\section{DAFTAR PUSTAKA}

Struthers AD. 2001. Are Natriuretic Peptides Clinically Useful as Marker of Heart Failure? Ann Clin Biochem ; 38: 94-102.

Gorenjak M. Kelly R and Natriuretic Peptides in Assessment of Ventricular Dysfunction. EJIFFCC: WWWW.ifcc.org/ejifcc.

Bhatia V, Nayyar P, Dhindsa S. 2003. Brain NatriureticPeptide in Diagnosis and Treatment of Heart Failure. NEJM ; 49: 182-185.

Denus S, Pharand C, and Williamson DR. 2004. Brain Natriuretic Peptide in The Management of Heart Failure. CHEST ; 125:652-668.

Hill JA. Diagnostic and Therapeutic Uses of Natriuretic Peptides in Patiens with Heart Failure. Tgila Web productions. http:// WWW.tgila.com/.

Peacock WF. 2002. The B-type Natriuretic Peptide Assay: A Rapid Test for Heart Failure. Cleveland Clinic Journal of Medicine ; 69: 243-251.

Levin ER, Gardner DG, Samson WK. 1998. Natriuretic Peptides. NEJM ; 339: 321-328.

Francis GS. Gassler JP, Sonnenblick EH. 2001. Pathophisiology and Diagnosis of Heart Failure. in The Heart $10^{\text {th }} \mathrm{Ed}$. Mc Graw-Hill ; 655-685.

Jessup M and Brozena S. 2003. Heart Failure. NEJM ; 348: 2007-2017.

Schrier RW and Abraham WT. 1999. Hormones and Hemodinamics in Heart Failure. NEJM ; 341: 577-584.

Ruscoaho H. 2003. Cardiac Hormones as Diagnostic Tools in Heart Failure. Endocrine Reviews ; 24: 341-356.

Sagnella GA. 2001. Measurement and Importance of Plasma Brain Natriuretic Peptide and Related Peptides. Ann Clin Biochem ; 38: 83-93.

Stein et al. 1998. Natriuretic Peptides: Phisiology, Therapeutic Potensial, and Risk Stratification 
in Ischemic Heart Disease. Am Heart J ; 135: 914-923.

Cowie MR et al. 2003. Clinical Aplications of BType Natriuretic Peptide (BNP) testing. European Heart Journal ; 24: 1710-1718.

Mark DB and Felker GM. 2004. B-Type Natriuretic Peptide - A Biomarker for All Seasons. NEJM ; 350:718-720.

Hobbs FDR, Roalfe AK, Hare Rdavies MK. 2002. Reability of N-Terminal pro- Brain Natriuretic Peptide Assay in diagnosis of Heart failure: Cohort Study in Representative and High Risk Community Populations. BMJ ; 324 .

Maisel AS et al. 2002. Rapid Measurement of BType Natriuretic Peptide in The Emergency Diagnosis of Heart Failure. NEJM ; 347:14. Mueller C et al. 2004. Use of B-Type Natriuretic Peptide in The Evaluation and Management of Acute Dyspnea. NEJM ; 350: 647-654.

Cardarelli R and Lumicao TG. 2003. B-Type Natriuretic Peptide: A review of Its Diagnostic, Prognostic, and Therapeautic Monitoring Value in Heart failure for Primary Care Phisicians. J Am Broad Fam Pract ; 16: 327-333.

Nagaya N et al. 1998. Plasma Brain Natriuretic Peptide is A Biochemical Marker for The Prediction of progressive Ventricular Remodeling After Acute Myocardial Infarction. Am Heart ; 135: 21-28.

De Lemos JA et al. 2001. The Prognostic Value of B-Type Natriuretic Peptide in Patients with Acute Coronary Syndromes. NEJM ; 345.

Gardner RS, Ozalp F, Murday AJ, Robb SD, McDonagh TA. 2003. N-Terminal pro-Brain Natriuretic Peptide A new Gold Standard in Predicting Mortality in Patients with Advanced Heart Failure. European Heart Journal ; 24: 1735-1743.

Wang TJ et al. 2004. Plasma Natriuretic Peptide Levels and The Risk of Cardiovascular Events and Death. NEJM ; 350:655-663. 